\title{
BERBAHASA: POTRET NASIONALISME GENERASI BANGSA
}

\author{
'Sri Maryani, ${ }^{2}$ Erwin \\ ${ }^{1,2}$ Dosen Program Studi Pendidikan Bahasa, Sastra Indonesia dan Daerah, Universitas Muhammadiyah \\ Mataram
}

\begin{abstract}
ABSTRAK
Keheterogenan dalam kehidupan berbangsa adalah suatu keniscayaan yang harus diterima sebagai realitas kekayaan budaya dan suku bangsa, serta mesti terpelihara dan terjaga oleh segenap masyarakat penggunanya.Oleh karena itu, bahasa mesti dipahami sebagai salah satu kekayaan nasional yang dimiliki oleh bangsa Indonesia. Setidaknya terdapat 700 bahasa daerah yang tersebar di 34 provinsi di Indonesia. Dengan demikian, maka bahasabahasa daerah tersebut menjadi ciri dan indentitas bagi para penuturnya. Selain bahasa-bahasa daerah tersebut, kita juga mengenal bahasa Indonesia yang berkedudukan sebagai bahasa Nasional dan bahasa Negara, sebagaimana yang tertuang dalam butir ke- 3 ikrar sumpah pemuda dan tercantum di dalam pasal 36 BAB XV UUD 1945. Selain itu, kita juga dihadapkan dengan hadirnya bahasa-bahasa Asing sebagai bagian dari perkembangan arus globalisasi yang luar biasa dahsyatnya. Kondisi ini menjadi embrio terjadinya kontak bahasa yang berujung pada konsistensi dan kecenderungan berbahasa (sikap bahasa) yang berbeda-beda. Berangkat dari landasan sebagaimana dideskripsikan di atas, maka dalam tulisan ini akan disajikan berbagai fenomenafaktual mengenai ekistentesibahasa Indonesia sebagai bahasa Nasional dan bahasa Negara yang tercermin dalam berbagai aktifitas sosial. Beberapa hal yang akan disajikan terkait kedudukan bahasa Indonesia yang dimaksud, diantaranya: (1) Kecenderungan perilaku berbahasa;(2) pembelajaran bahasa Indonesia; dan (3) hasil Ujian Akhir Nasional (UAN); antara kualitas berbahasa danbukti nasionalisme. Secara substansial tulisan ini bertujuan untuk merefleksi realitas dan kemampuan berbahasa masyarakat Indonesia pada umumnya, guna menakar kualitas nasionalisme generasi bangsa. Dengan demikian, tulisan ini diharapkan dapat menjadi ilustrasi bagi para pembaca untuk ikut berkontribusi; (a) mengapresiasi penggunaan bahasa sesuai dengan konteksnya, dan (b) mendorong berbagai pihak terkait untuk berupaya meningkatkan kualitas pembelajaran dan prestasi belajar Bahasa Indonesia.
\end{abstract}

Kata kunci: berbahasa, nasionalisme, generasi bangsa

\section{Pengantar}

Bahasa memiliki peranan yang sangat penting dalam kehidupan bermasyarakat. Dengan bahasa, sesorang dapat mengungkapkan pikirannya secara khas yang memperlihatkan jiwa dan kepribadiannya. Dengan bahasa pula seseorang mendapatkan efek tertentu, baik efek praktis untuk menarik perhatian dalam percakapan sehari-hari maupun efek estetis dalam karya sastra, dan dengan bahasa seseorang dapat mencapai tujuannya dalam segala bidang. Gaya berbahasa seseorang, baik lisan maupun tulisan secara tidak langsung dapat mencerminkan kualitas diri orang tersebut. Istilah bahasa Indonesia yang baik dan benar tentunya tidak bisa kita terjemahkan secara sempit, karena baik belum tentu benar dan benar belum tentu baik. Kemampuan seseorang berbahasa/berkomunikasi secara baik berkaitan dengan kemampuannya memahami kapan, dimana, dan dengan siapa dia berkomunikasi, sementara kemampuan seseorang berbahasa/berkomunikasi secara benar berkaitan dengan aturan dan sistem dalam berbahasa, seperti unsur gramatikal, EYD maupun sistem tanda yang lain dalam berbahasa.

Ada fenomena menarik dalam dunia pendidikan kita yang terkait dengan pengajaran bahasa terutama bahasa Indonesia, yakni belum tercapainya hasil yang memuaskan. Padahal pemerintah/stake holder sudah melakukan berbagai macam upaya dalam menghasilkan peserta didik yang berkualitas, seperti menyediakan Lembaga Pendidikan Tenaga Kependidikan (LPTK), penyempurnaan kurikulum, pelatihan guru bahasa, PLPG dan lain sebagainya. Namun capaian hasil pembelajaran bahasa Indonesia masih berada di bawah standar, bahkan ironis nya, nilai pelajaran bahasa Indonesia menjadi salah satu nilai terendah dari sekian mata pelajaran yang di ujikan pada ujian nasional. Hal ni sungguh menjadi cambukan berat bagi para tenaga pendidik seperti kita, apakan kita harus 
menyalahkan pemerintah, peserta didik, atau kita sebagai tenaga pendidik? Kenapa bahasa Indonesia yang merupakan bahasa nasional dan alat komunikasi sehari-hari bangsa ini justru menjadi mata pelajaran yang dapat "menyumbangkan" kegagalan bagi peserta didik kita?

Jika dilihat dari segi kompetensi, mungkin kita dapat mengelompokkan mana siswa yang memiliki kemampuan berbahasa Indonesia yang baik, yang sedang atau yang rendah. Tetapi, jika dilihat dari segi "kepemilikan", semua peserta didik harusnya merasa memiliki bahasa Indonesia, mau menggunakannya dalam komunikasi sehari-hari dan juga bangga dengan "kepemilikan" tersebut. Realitanya, banyak dari peserta didik kita yang merupakan generasi muda penerus bangsa yang justru tidak mampu menentukan sikap terhadap penggunaan bahasa, tidak tahu kapan konteks yang tepat dalam memilih bahasa, dan hal ini menunjukkan rendahnya rasa nasionalisme mereka.

\section{Pembahasan}

\section{A. Kecenderungan Perilaku Berbahasa}

Salah satu identitas suatu bangsa adalah bahasa yang digunakan oleh segenap masyarakatnya. Indonesia sebagai negara kepulauan dengan keanekaragaman suku bangsa yang begitu unik, sudah tentu akan melahirkan identitas dan corak yang sangat beragam. Bahasa adalah salah satu ciri unik dan khas yang dimiliki suatu bangsa, termasuk bangsa Indonesia. Setidaknya ada sekitar \pm 700 bahasa yang menjadi identitas dan corak bagi suku-suku bangsa yang kita kenal sebagai bahasa daerah, dan tersebar di seantero bumi Indonesia, serta bahasa Indonesia sebagai identitas nasional yang berperan menyatukan suku-suku bangsa. Dengan demikian dapat kita pastikan, terdapat perbedaan sikap dan perilaku terhadap bahasa-bahasa tersebut.

Berbahasa adalah perilaku sosial yang dapat kita amati perkembanganya dari waktukewaktu. Telah nampak dihadapan kita, bahwa ada peristiwa pergeseran perilaku/sikap berbahasa yang ditunjukan oleh generasi bangsa. Realitas berbahasa Indonesia adalah wujud nyata dari terimplementasikanya ikrar sumpah pemuda 28 Oktober 1928. Hal ini akan bermakna positif, jika disikapi secara proporsional. Maksudnya, kewajiban berbahasa Indonesia tidak berarti menjauhi, meninggalkan, bahkan melupakan bahasa-bahasa lainnya. Namun mestinya, bahasa-bahasa tersebut digunakan sesuai dengan konteks dan situasi yang tepat.

Bahasa Indonesia kini menjadi alat interaksi verbal yang sangat diapresiasi oleh generasi bangsa. Hampir di setiap aktifitas sosial, baik pada situasi formal maupun tidak formal/santai bahasa Indonesia menjadi prioritas pilihan. Perilaku berbahasa semacam ini disatu sisi sangat menguntungkan bagi eksistensi bahasa Indonesia sebagai bahasa nasional, namun disisi lain mengancam eksistensi bahasa-bahasa daerah yang menjadi bagian dari kekayaan nasional bangsa. Dominasi perilaku berbahasa Indonesia yang ditunjukkan oleh generasi bangsa saat ini tidak dapat dipandang sebagai sikap yang wajar-wajar saja. Sebab sikap tersebut ditunjukkan dengan motifmotif yang tidak mendasar, yaitu berbahasa Indonesia karena mereka beranggapan; (1)bahasa Indonesia adalah ciri/identitas orang kaya, (2) bahasa Indonesia adalah ciri/identitas orang kota, (3) bahasa Indonesia adalah bahasa orang yang berpendidikan tinggi, (4) bahasa Indonesia dapat menyembunyikan latar belakang sosial/identitas asli, dan seterusnya. Dengan kata lain, berbahasa Indonesia adalah upaya pencitraan positif terhadap diri penggunanya.

Sementara itu, fenomena yang berbeda telah diperlihatkan oleh generasi masa lalu yang kini masih juga diwarisi oleh komunitas pedalaman atau masyarakat pedesaan yang masih memiliki corak kehidupan yang primitif. Bagi mereka, berbahasa Indonesia adalah perilaku/sikap sosial berupa penggunaan simbol-simbol verbal yang bermakna kesombongan, keangkuhan, kurangajar, dan tidak sopan. Memasuki era persaingan global, kini generasi kita nampaknya memberikan apresiasi yang luar biasa terhadap bahasa Inggris. Gejala perubahan sikap/prilaku berbahasa yang diperlihatkan saat ini patut dikahwatirkan, sebab fenomena seperti ini dapat mengancam eksistensi bahasa Indonesia sebagai bahasa Nasional. Dengan kata lain, bahasa Inggris dan bahasa Asing lainya dapat menggeser eksistensi bahasa Indonesia di Nusantara.

Keadaan sebagaimana yang dideskripsikan di atas mengandung makna yang ambigu. Disatu sisi kita dapat merasakan adanya perilaku/sikap positif terhadap bahasa yang satu, namun disisi lain menunjukkan prilaku/sikap negatif terhadap bahasa-bahasa yang lainya. Mestinya kita dapat berbahasa secara proporsional, yaitu; berbahasa Indonesia 
untuk interaksi sosial antarsuku (suku yang berbeda), berbahasa daerah saat interaksi intrasuku (sesama suku), dan berbahasa Asing saat interaksi antarnegara (dengan orang yang berasal dari bangsa lain). Dengan demikian secara politis, Indonesia memiliki kedaulatan berbahasa.Sabagaimana yang dikatakan oleh Holmes (1992: 369), bahwa bahasa kita merupakan unsur sangat penting bagi suatu Negara dan bahasa harus dijadikan raja kurikulum bagi generasi bangsa.

\section{B. Pembelajaran Bahasa Indonesia}

Bahasa Indonesia adalah salah satu mata pelajaran yang dikehendaki oleh undangundang, sebagaimana yang diamanahkan pada pasal 36 BAB XV UUD 1945. Pembelajaran bahasa apa pun, baik yang dilakukan oleh lembaga pendidikan formal, maupun nonformal pada prinsipnya diperuntukan sebagai upaya menguasai bahasa yang dipelajari itu agar dapat digunakan sebagai sarana komunikasi. Ada tiga hal pokok yang terkait dengan keberhasilan pembelajaran suatu materi termasuk materi bahasa Indonesia, yaitu masalah substansi, pendekatan, dan motivasi belajar. Masalah substansi pembelajaran menyangkut isi/materi pembelajaranyang disajikan itu sudah memenuhi kategori untuk membuat pembelajar dapat menggunakan bahasa Indonesia secara baik dan benar.

Adapun masalah pendekatan, terkait dengan apakah metode yang digunakan dalam pembelajaran materi itu sudah relevan sehingga pembelajar dapat menangkap isi/kandungan materi pembelajarantersebut. Selanjutnya, motivasi belajar terkait dengan persoalan psikologis untuk apa suatu materi pembelajaran itu dikuasai. Adakah faktor-faktor emosional yang dapat mengikap pembelajaran sehingga terdorong untuk mempelajari materi pembelajaran tersebut. Faktor motivasi merupakan faktor yang sangat penting dan terintegrasi di setiap proses pembelajaran itu berlangsung.Ketiga hal ini akan menjadi sorotan utama dalam menjawab persoalan mengapa pembelajaran bahasa Indonesia dalam dunia pendidikan kita belum membawa hasil yang memuaskan bagi pencapain tujuan pembelajaran materi tersebut, yaitu agar peserta didik dapat menggunakan bahasa Indonesia baik lisan maupun tulisan secara baik dan benar.

Kegiatan pembelajaran bahasa Indonesia kini telah berlangsung \pm 25 abad lamanya (lihat Kelly, 1976). Berbagai metode dan pendekatan pembelajaran bahasa telah digunakan untuk mencapai tujuan pembelajaran. Secara garis besar ada dua tekanan substansi pembelajaran bahasa pada umunya yang diadopsi kedalam pembelajaran bahasa Indonesia, yaitu pembelajaran dengan fokus utamanya pada bentuk (form) bahasa dan pembelajaran dengan fungsi (fungtion) bahasa. Apabila pada pembelajaran dengan penekanan pada bentuk bahasa lebih difokuskan pada penguasaan struktur (tata bahasa), maka pada pembelajaran dengan penekan pada fungsi bahasa lebih difokuskan pada penguasaan penggunaan bahasa. Hymes (1971) menjelaskan bahwa terdapat kaidah-kaidah penggunaan bahasa yang tanpa itu kaidahkaidah tata bahasa tidak akan ada gunanya.

$$
\text { Degan demikian, mestinya }
$$

pembelajaran bahasa Indonesia tidak sekedar memberikan pengetahun tentang bahasa melainkan harus berorientasi pada peningkatan kemampuan menggunakan bahasa Indonesia yang bermutu (berbahasa Indonesia yang baik, benar, dan tepat). Selain itu, haruslah diingat bahwa kewajiban berbahasa Indonesia bukanlah sebuah tanggung jawab yang dilemparkan kepada guru bahasa Indonesia saja, tetapi merupakan amanah yang harus diembani oleh segenam komponen dan insan bangsa Indonesia. Oleh karena itu, pada setiap momentum-mementum yang formal wajib bagi kita menggunakan bahasa Indonesia sebagai bentuk apresiasi terhadap bahasaoleh segenam komponen dan insan bangsa Indonesia. Oleh karena itu, pada setiap momentum-mementum yang formal wajib bagi kita menggunakan bahasa Indonesia sebagai bentuk apresiasi terhadap bahasa nasional dan bahasa resmi negara.

\section{Hasil Ujian Akhir Nasional (UAN); Antara Kualitas Berbahasa dan Bukti Nasionalisme}

Ujian Nasional (UN) adalah peristiwa tahunan yang menggegerkan dunia pendidikan. Peraturan Menteri Pendidikan Nasional Republik Indonesia Nomor 48 Tahun 2006 tentang Ujian Nasional (UN) pasal 3 mengamanahkan, bahwa Ujian Nasoonal bertujuan menilai pencapaian kompetensi lulusan secara nasional pada mata pelajaran tertentu dalam kelompok mata pelajaran tertentu dalam kelompok mata pelajaran ilmu pengetahuan dan teknologi. Pasal 4 berbunyi: Hasil UN digunakan sebagai salah satu pertimbangan untuk: 1) pemetaan mutu satuan dan/atau program pendidikan; 2) 
seleksi masuk jenjang pendidikan berikutnya; 3) penentuan kelulusanpeserta didik dari satuan pendidikan; 4) akreditasi satuan pendidikan; dan 5) pembinaan dan pemberian bantuan kepada satuan pendidikan dalam upaya meningkatkan mutu pendidikan. Peraturan ini menjadi pegangan atau landasan bagi sekolah untuk melaksanakan UN di sekolah dan menindaklanjutinya.

Ujian Nasional (UN) adalah salah satu agenda nasional bangsa ini. Agenda bangsa Indonesia yang dihajadkan untuk melakukan evaluasi terhadap pencapai kompetensi lulusan. Beberapa tahun terakhir hasil UN mata pelajaran bahasa Indonesia berada pada peringkat bawah dibandingkan mata pelajaran lain (bahasa Inggris, IPA). Berdasarkan data dari Kemendikbud, sebagian besar kasus ketidaklulusan siswa dalam ujian nasional (UN) disebabkan jebloknya nilai pelajaran bahasa Indonesia. Kemendikbud menemukan, rata-rata mata pelajaran bahasa Indonesia menjadi momok bagi siswa. "Banyak siswa yang tidak lulus UN dan harus mengulang karena salah satu mata pelajaran tidak memenuhi syarat, terutama bahasa Indonesia," kata Nuh (26/4).

Rendahnya nilai (angka) bahasa Indonesia terjadi pada setiap UN sebagaimana yang kita dengar selama ini. Data yang memperkuat bahwa mata pelajaran bahasa Indonesia menjadi momok dalam ujian nasional adalah data yang dilangsir oleh Mendikbud pada 2011, bahwa sekitar 14 ribu dari 26 ribu siswa yang tidak lulus ujian nasional terganjal di mata pelajaran bahasa Indonesia. Sebagai akademisi (pengajar dan pemerhati) pembelajaran bahasa Indonesia kenyataan ini sungguh miris, terlebih lagi bila melihat pasal 4 nomor 3 peraturan menteri Pendidikan Nasional tentang UN di atas. Beberapa pertanyaan mendasarpun bermunculan terkait masalah ini, apa penyebab rendahnya nilai UN bahasa Indonesia? Rumusan tujuan pembelajaran, materi pelajaran, kurikulum, kompetensi guru, alat ukur/tes, ataukah penyusunan tes? Terkait rentetan pertanyaan itu, sejumlah jawaban spekulatif pun bermunculan. Salah satu di antaranya memberikan tangapan, bahwa kesimpulan evaluasi mengenai hasil UN mata pelajaran bahasa Indonesia yang sangat rendah tersebut disebabkan oleh lemahnya kemampuan dalam membaca. Hal ini mengakibatkan peserta UN kehabisan waktu untuk mengerjakan soal.

Di dalam kurikulum, tujuan Mata Pelajaran Bahasa Indonesia yang berkaitan dengan kemampuan berbahasa adalah peserta didik memiliki kemampuan: (1) berkomunikasi secara efektif dan efisien sesuai dengan etika yang berlaku, baik secara lisan maupun tulis; (2) memahami bahasa Indonesiadan menggunakanya dengan tepat dan kreatif untuk berbagai tujuan; dan (3) menggunakan bahasa Indonesiauntuk meningkatkan kemampuan intelektual, serta kematangan emosional dan sosial. Apakah ini berarti telah terjadi kegagalan terhadap upaya pencapaian tujuan Mata Pelajaran Bahasa Indonesia? Jika iya, maka benarkah generasi bangsa ini sedang mengalami kebangkrutan nasionalisme?

Harus diakui, bahwa apa yang diperlihatkan lewat UN adalah merupakan salah satu indikator yang memalukan bagi bangsa ini, sebuah fakta yang memprihatikan mengenai kualitas generasi bangsa yang telah gagal membuktikan nasionalismenya sebagaimana yang telah diikrarkan dalam butir ke-3 sumpah pemuda yang dilakukan pada 28 Oktober 1928. Makna tercederainya nasionalismedalam konteks ini merupakan terjemahan terhadap hasil UN yang mendeskripsikan, bahwa masih banyak generasi bangsa ini yang belum mampu berkomunikasi secara efektif dan efisien sesuai dengan etika yang berlaku baik secara lisan maupun tulis, serta masih ada yang belum dapat memahami bahasa Indonesia dan menggunakanya dengan tepat dan kreatif untuk berbagai tujuan, sehingga tidak rerjadi peningkatan kemampuan intelektual, serta kematangan emosional dan sosial.

\section{Penutup}

Nampak jelas, bahwa prilaku berbahasa yang diperlihatkan masyarakat Indonesiadari waktu kewaktu mengalami pergeseran. Jika pada masa lalu masyarakat Indonesia cenderung memperlihatkan sikap negatifnya terhadap bahasa Indonesia, karena bahasa Indonesia dianggap tabu(sebagai akibat dari peradaban masyarakat yang masih primitiff.Kini sikap tersebut telah berubah menjadi sikap positif yang ditampakkan lewat interaksi sosial sehari-hari yang didominasi oleh penggunaan bahasa Indonesia. Apresiasi terhadap penggunaan bahasa Indonesia dimasa kini memang sungguh menggembirakan, namun kini telah nampak bahwa pada masa-masa yang akan datang apresiasi terhadap penggunaan bahasa Indonesia akan tergeser atau dihegemoni oleh penggunaan bahasa Inggris (bahasa Asing lainya) sebagai akibar dari dampak eraglobalisai. 
Sementara itu, jika kita amati pembelajaran bahasa Indonesia yang berlangsung di lembaga pendidikan baik formal, maupun non formal maka kita dapatkan adanya fakta yang mengecewakan. Peserta didik nampaknya memperlihatkan sikap optimisme terhadap kemampuan berbahasa yang dimilikinya, namun pada satu sisi kondisi ini tidak berbanding lurus dengan motivasi dirinya terhadap proses pembelajaran bahasa Indonesia. Sebagai akabitnya, maka Ujian Nasional (UN) telah mencatat sejarah buruk dan mempersembahkan raport merah terhadap pembelajaran bahasa Indonesia. Mata Pelajaran Bahasa Indonesia menjadi momok bagi prestasi dan indikator terpuruknya kualitas pendidikan.

Akhirnya perilaku berbahasa, pembelajaran bahasa, serta kemampuan berbahasa Indonesia kini telah menyandera nasionalisme generasi bangsa. Catatan kelam dunia pendidikan ini mudah-mudahan dapat diakhiri. Oleh karena itu, untuk membebaskan nasionalismegenerasi bangsa dari penyanderaan kedaulatan berbahasa dapat dilakukan dengan terus menumbuhkan sikap positif terhadap penggunaan bahasa Indonesia, serta terus meningkat kualitas pembelajaran bahasa di lembaga-lembaga pendidikan.

\section{Daftar Pustaka}

Alisjahbana, Sutan Takdir.1981. Tata Bahasa Baru Bahasa Indonesia 1. Jakarta: Dian Rakyat.

Bowden, Jhon, dkk. 2012. Bahasa, Sastra, dan Pengajaranya. Singaraja: FPBS Undiksha.

Holmes, Janet. 1992. An Introduction to Sosiolinguistics. London: Langman.

Hyme, Dell.1972. On Comunicative Competence. University of Pennsylvan Press, Inc.

Setiawati, Lis. 2012. Evaluasi Hasil Belajar Bahasa Indonesia Siswa SMA tahun 2011. Makalah Semnas ke-Il di Singaraja-Bali.

Wardaugh, Ronald. 1998. An Introduction to Sosiolinguistics. Oxford: Basil Blaekwell Ltd.

Arbai.2013. Nilai Ujian Nasional Bahasa Indonesia (online). http://budisansblog.blogspot.com/2013/0 5/nilai-uiian-nasional-bahasaIndonesia.html. Diakses 02 September 2014 